\title{
KETERKAITAN ISI SIARAN TELEVISI DI INDONESIA DAN KEADILAN INFORMASI
}

\author{
Erni Herawati \\ Jurusan Marketing Communication, Fakultas Ekonomi dan Komunikasi \\ Universitas Bina Nusantara \\ Jln. K.H. Syahdan No. 9, Palmerah, Jakarta Barat 11480
}

\begin{abstract}
Indonesian Television Broadcasting has been progressing rapidly both in number of television stations and programs. In fact, almost all of national private televisions broadcasting programs were always about Jakarta. Article aimed to analyze on how the function of media which was not only provided information but it also supported the values of community and its sustainability. It related to the media content. The media content was not only determined by internal media factors but also the external ones. Finally, the owners of the media became the one who determined how media content was produced and formed. Therefore, to avoid information which was not monopolized by one party, the community should have various informations to choose. Finally, it is concluded that rules in broadcasting television has to consider the equality of information for people.
\end{abstract}

Keywords: media functions, media content, media ownership, and the equality of information

\begin{abstract}
ABSTRAK
Dunia pertelevisian Indonesia saat ini telah mengalami perkembangan pertumbuhan yang cukup pesat, baik dari segi jumlah stasiun televisi maupun program. Kenyataannya, hampir semua lembaga penyiaran swasta nasional hanya menyiarkan program mengenai Jakarta. Artikel menganalisis fungsi media massa, termasuk penyiaran yang berkaitan dengan isi media yang disampaikan. Isi media tidak hanya ditentukan oleh faktor internal media tetapi juga faktor eksternal. Kepemilikan media akhirnya menentukan bagaimana isi media yang diproduksi dan dibentuk. Oleh karena itu, agar informasi tidak hanya dimonopoli oleh satu golongan dan masyarakat mendapat pilihan informasi yang beragam dan sesuai dengan yang dibutuhkan maka perlu dipastikan agar keberagaman itu dimulai dari kepemilikan dari media. Disimpulkan, aturan main dalam dunia penyiaran harus mempertimbangkan kepentingan masyarakat sehingga akan membawa keadilan informasi bagi masyarakat khususnya di Indonesia.
\end{abstract}

Kata kunci: fungsi media, isi siaran, kepemilikan media, dan keadilan informasi 


\section{PENDAHULUAN}

Siaran televisi swasta nasional - meskipun istilah ini sebenarnya tidak dikenal dalam aturanaturan tentang penyiaran di Indonesia - pada dasarnya sangat "Jakarta". Bagi Anda yang tinggal di Pulau Jawa, maka informasi seputar Jakarta atau tempat lain di wilayah Pulau Jawa memang sangat perlu untuk diikuti karena kedekatan kita dengan informasi yang diberitakan, tetapi bagaimana dengan mereka yang tinggal di Papua atau utara Sulawesi? Selain itu dapat dilihat bahwa hampir semua produksi sinetron yang ditayangkan di televisi berlatar belakang situasional Jakarta, sedangkan stasiun televisi tersebut jangkauan siarannya hampir meliputi seluruh wilayah Indonesia yang terbentang dari Sabang sampai Merauke. Hampir semua stasiun swasta baru tidak melakukan perubahan, kecuali dalam aspek hiburan yang lebih variatif. Mereka justru meniru gaya TVRI dalam me-relay siaran Jakarta ke daerah yang dianggap potensial secara ekonomi. Tak pelak, apa yang dinikmati publik di Papua, Kalimantan, Sumatera, dan Jawa adalah berita, hiburan, dan iklan yang sama. Tidak ada perbedaan perlakuan untuk publik yang jelas-jelas secara kultural, sosiologis, dan ekonomi berbeda (Sudibyo, 2004: 100)

Itulah sekilas bentuk dunia pertelevisian, walaupun pertelevisian Indonesia saat ini sebetulnya telah mengalami perkembangan yang cukup pesat baik dari segi jumlah stasiun televisinya maupun dari jumlah program yang ditayangkannya. Bila ditengok kembali sejarah televisi Indonesia, maka yang pertama diingat adalah stasiun Televisi Republik Indonesia (TVRI). TVRI lahir menjelang diadakannya Asian Games ke-4 di Jakarta pada 1962. Saat itu, Soekarno dan kabinet akhirnya yakin akan perlunya televisi dengan alasan reputasi internasional Indonesia tergantung pada pekan olah raga yang disiarkan, terutama ke Jepang yang telah memiliki televisi sejak awal 1950-an (Mufid, 2005: 47). Setelah siaran percobaan pada 17 Agustus 1962, TVRI menyiarkan peristiwa internasional Asian Games IV, ke penjuru dunia. Sebagai negara ke-4 di Asia yang memiliki televisi setelah Jepang, Filipina dan Thailand, Indonesia memasuki babakan baru dalam memanfaatkan medium televisi untuk kepentingan bangsa Indonesia (Nugroho, 2002: vii)

Gagasan pembangunan siaran televisi di Indonesia sejak semula adalah untuk pendidikan nasional. Artinya, misinya adalah demi kepentingan publik. Untuk itulah, pemerintah Indonesia yang pada 1962 dipimpin oleh Presiden Soekarno mendirikan TVRI (Nugroho, 2002: vii). Televisi merupakan medium yang paling cepat berkembang di awal tahun 1980-an, dalam jumlah pesawat dan kebiasaan menonton orang Indonesia. Selama dekade ini jumlah pesawat televisi bertambah 6 kali lipat, sementara radio meningkat 3 kali (Mufid, 2005: 55).

Saat ini Indonesia memiliki jumlah stasiun radio dan televisi terbesar di dunia setelah Cina, dengan perincian 10 Stasiun TV Swasta Nasional, 70 TV Swasta Lokal, 2 TV Kabel, 1 TV Satelit, serta lebih dari 1800 Stasiun Radio (www.seputar-indonesia.com/edisicetak/content/view/397493/44/). Kelahiran stasiun televisi swasta di Indonesia dimulai pada tahun 1988 yaitu dengan kehadiran stasiun televisi Rajawali Citra Televisi Indonesia (RCTI) yang memulai dengan siaran percobaan (Mufid, 2005: 52), sehingga bisa penulis disimpulkan bahwa selama kurun waktu dari mulai tahun 1962 sampai tahun 1988 tersebut siaran televisi di Indonesia dimonopoli oleh siaran dari TVRI baik siaran nasional maupun lokal. Kelahiran RCTI kemudian disusul oleh kelahiran stasiun-stasiun televisi swasta lainnya. Masing-masing dari stasiun televisi swasta tersebut berlomba-lomba untuk memperluas cakupannya ke hampir seluruh wilayah Indonesia.

Saat ini sudah ada aturan main bagi industri penyiaran di Indonesia yaitu untuk penyiaran radio dan televisi melalui Undang-undang Nomor 32 Tahun 2002 tentang Penyiaran. Aturan ini menyatakan bahwa asas penyiaran di Indonesia antara lain adalah asas manfaat, adil dan merata, kepastian hukum, keamanan, keberagaman, kemitraan, etika, kemandirian, kebebasan, dan tanggung jawab (Pasal 2 UU No. 32 Tahun 2002). Dari asas tersebut bisa kita lihat bagaimanakah kondisi 
penyiaran yang diinginkan, namun sampai saat ini industri penyiaran di Indonesia masih terus dalam proses menyesuaikan dengan apa yang diamanahkan oleh undang-undang tersebut.

\section{METODE}

Artikel disusun menggunakan studi pustaka, yaitu informasi yang terkait dengan sejarah pertelevisian di Indonesia, permasalahan yang ada, fungsi media, kepemilikan media, dan keadilan informasi

\section{PEMBAHASAN}

Perkembangan teknologi dan informasi saat ini tumbuh dengan cepat. Jumlah media massa televisi yang berdiri di Indonesia juga semakin banyak, sehingga informasi yang tersedia saat ini menjadi begitu berlimpah. Namun demikian, apakah kekayaan informasi tersebut telah dapat menjamin terpenuhinya informasi yang sesuai dengan kebutuhan masyarakat? Sejalan dengan hal tersebut, apakah perkembangan industri informasi tersebut sudah dapat juga dinikmati oleh masyarakat yang menjadi sasaran dan serbuan informasi tersebut? Sementara saat ini kita mengetahui bahwa banyak televisi yang berjangkauan siaran hampir di seluruh wilayah Indonesia berkantor pusat di Jakarta dan isi siaran yang disampaikan juga mengenai seputar Jakarta. Masalah yang akan dianalisis adalah bagaimana sebenarnya fungsi media televisi bagi masyarakat Indonesia? dan bagaimana isi siaran televisi dipengaruhi dan apakah sudah menjamin keadilan informasi bagi masyarakat, terutama jika dikaitkan dengan bagaimana isi media tersebut dibentuk oleh institusi media?

\section{Fungsi media}

Media merupakan agen sosialisasi, karena media meningkatkan kohesi sosial dengan menampilkan budaya umum, pandangan-pandangan yang sudah terstandarisasi tentang budaya melalui komunikasi massa (Schaefer, 2011: 136). Dalam kajian komunikasi massa banyak disebutkan mengenai beberapa fungsi media massa, termasuk didalamnya adalah media massa televisi. Fungsi media dalam masyarakat menurut Mc.Quail (2000: 79) antara lain adalah : 1) Fungsi informasi, yaitu untuk memberikan informasi tentang kejadian-kejadian dan kondisi-kondisi dalam masyarakat dan dunia, mengindikasikan hubungan-hubungan kekuasaan, dan memfasilitasi inovasi, adaptasi dan kemajuan; 2) Fungsi korelasi, yaitu untuk menjelaskan, menginterpretasikan, dan mengomentari makna tentang kejadian-kejadian dan informasi, memberikan dukungan bagi otoritas dan normanorma yang ada, sosialisasi, mengkoordinasikan aktivitas-aktivitas yang terpisah, dan membangun konsensus; 3) Fungsi keberlanjutan, yaitu untuk mengekspresikan budaya dominan dan memperkenalkan budaya subculture dan perkembangan budaya-budaya baru, dan menekankan dan mengelola nilai-nilai bersama; 4) Fungsi hiburan, yaitu untuk memberikan kesenangan, keragaman, dan sarana untuk relaksasi, mengurangi ketegangan sosial; 5) Fungsi mobilisasi, yaitu untuk mengkampanyekan tujuan-tujuan sosial di wilayah politik, ekonomi, peperangan, pembangunan ekonomi, pekerjaan dan bahkan agama.

Dari kesemua fungsi tentang media yang diuraikan tersebut, secara khusus fungsi penyiaran di Indonesia dapat dilihat dalam Undang-undang Penyiaran yang disebutkan bahwa penyiaran sebagai kegiatan komunikasi massa berfungsi antara lain sebagai media informasi, pendidikan, hiburan yang sehat, dan juga mempunyai fungsi ekonomi dan kebudayaan (Pasal 4 UU No. 32 Tahun 2002). Asas penyiaran di Indonesia antara lain adalah asas manfaat, adil dan merata, kepastian hukum, keamanan, 
keberagaman, kemitraan, etika, kemandirian, kebebasan, dan tanggung jawab (Pasal 2 UU No. 32 Tahun 2002). Selain itu dikaitkan tujuan penyelenggaraan penyiaran yaitu : untuk memperkukuh integrasi nasional, terbinanya watak dan jatidiri bangsa, memajukan kesejahteraan umum dalam rangka membangun masyarakat yang mandiri, demokratis, adil dan sejahtera, serta menumbuhkan industri penyiaran Indonesia (Pasal 3 UU No. 32 Tahun 2002).

\section{Kepemilikan Media dan Pengaruhnya Terhadap Isi}

Shoemaker dan Reese (1996: 3) menyatakan bahwa isi media dapat dipengaruhi oleh beberapa level yang dimulai dari yang paling kecil yaitu : 1) level individual; 2) level ru tinitas media; 3) level organisasi; 4) level ekstra media; 5) level ideologi. Dari eksternal media televisi dapat kita sebutkan pihak-pihak mana yang punya kepentingan, antara lain yaitu: 1) pemerintah, sebagai pihak yang harus mengatur dan mengontrol pelaksanaan dan aturan main bagi keberadaan media di masyarakat; 2) investor, sebagai pihak yang selalu menargetkan keuntungan bagi modal yang telah ditanamkan dalam perusahaan media; 3) pengiklan, berkepentingan terhadap penjualan produk yang diiklankan dalam program televisi yang ditayangkan; dan 4) masyarakat, yang menjadi tolok ukur bagi media televisi tentang apa program/acara yang disukai dan yang tidak disukai, yang seringkali diukur melalui berapa jumlah rating sebuah acara, dimana rating ini pulalah yang menjadi sebab sebuah acara televisi dapat mendatangkan pengiklan yang banyak atau tidak. Seperti yang dikatakan oleh Shoemaker and Reese (1996: 219) bahwa bagi sebagian besar media komersial, audiens menempati posisi cukup penting karena perhatian mereka dapat dijual kepada pengiklan, yaitu pihak yang dapat memberikan keuntungan yang besar. Dan pengiklan seringkali memberitahu media apa yang mereka pikirkan dan bagaimana mereka percaya bahwa bagaimana isi media seharusnya diubah.

Selain analisis menurut faktor eksternal, kita dapat menganalisis komunikasi massa dari sudut internal media. Penelitian media-sentris lebih menekankan pada pengaruh organisasi terhadap isi media atau konten yang dihasilkannya. Mc. Quail menyatakan (dalam Morissan dkk, 2010: 41) bahwa media-sentris mendukung pandangan bahwa isi media secara sistematis dan jelas dipengaruhi oleh rutinitas atau kebiasaan organisasi, tindakan dan tujuan dari berbagai faktor personal atau ideologi. Kepemilikan dan kontrol memengaruhi isi media atau bahwasannya setiap proses produksi massa memberikan pengaruh secara sistematis terhadap konten. Selanjutnya dia mengatakan bahwa tidak diragukan lagi pemilik organisasi media komersil memiliki kekuasaan besar terhadap isi media dan dapat meminta profesional media untuk menyiarkan atau tidak menyiarkan suatu isi media (Morissan dkk, 2010: 53).

Menurut Bimo (dalam Sudibyo, 2004: ix) pada dasarnya penyiaran (radio dan televisi) merupakan instrumen keterbukaan dan demokratisasi, Open Sky Open Society, langit terbuka masyarakat terbuka. Oleh sebab itu semesta penyiaran perlu dilindungi dari intervensi negara dan penetrasi pasar yang berlebihan. Karena penyiaran adalah public spheres, sebuah ruang atau kawasan dimana publik bisa menayangkan wacana yang demokratis dan rasional.

Industri media memang mempunyai kecenderungan untuk dimiliki oleh segelintir orang yang memang memiliki modal yang cukup besar, seperti yang diutarakan oleh Schaefer (2011: 152) memberikan pertanyaan "Siapa yang memiliki produksi media dan proses distribusi? Jawabannya adalah sejumlah kecil dari begitu banyak korporasi. Dalam analisisnya, fungsionalis melihat konsentrasi media - atau biasa disebut sebagai konsolidasi dalam setiap bisnis - adalah sebuah langkah untuk mendapatkan efisiensi ekonomi yang lebih besar, karena konsolidasi mengurangi biaya operasi, membebaskan penambahan modal dalam pengembangan bidang kreatif.

Memang diketahui bahwa, bisnis penyiaran televisi adalah bisnis yang padat modal. Uang yang harus ditanamkan untuk bisnis televisi jauh lebih mahal dari modal untuk bisnis media cetak atau penyiaran radio. Tingkat persaingan antar stasiun televisi juga jauh lebih keras, baik dalam 
meperebutkan kue iklan, pemirsa, tayangan-tayangan impor atau lokal terbaik, bahkan sampai pada persaingan untuk memperebutkan SDM berkualitas (Sudibyo, 2004: 54). Para pengelola televisi tampaknya kerepotan memenuhi tuntutan-tuntutan produksi ketika televisi telah menjadi entitas komersial. Mereka harus mempersiapkan sekian banyak acara untuk mengisi jam siaran yang semakin hari semakin panjang (Sudibyo, 2004: 63). Kalangan production house yang berusaha menopang kebutuhan program stasiun televisipun pada akhirnya tidak bisa menghindar dari kecenderungan "mencangkok" format dan logika cerita asing ala opera sabun atau film India. Dan ketika sampai pada suatu titik kebutuhan tayangan televisi tetap belum terpenuhi, maraklah pemutaran ulang serial-serial yang sudah disiarkan (re-run), atau mendaur ulang film layar lebar dalam format sinetron (remark) . Tanpa banyak disadari pemirsa, sinetron, komedi, dan acara televisi lainnya sebenarnya "serupa tapi tak sama". Judul boleh berbeda, aktor boleh berganti, namun format cerita, logika kisah, plot, penokohan, dan setting cerita sesungguhnya serupa (Sudibyo, 2004: 63).

Pada dasarnya pemilikan media penyiaran dapat saja dimiliki pemerintah, korporasi bisnis ataupun publik. Sementara orientasi fungsional atas media penyiaran biasa, harus diatur melalui regulasi yang menjaga agar fungsi untuk kepentingan bisnis (komersial) dan publik (kultural) harus tetap tercermin dalam orientasi media penyiaran (Siregar dalam Nugroho, 2002: 6). Pemilikan stasiun penyiaran harus dibedakan dengan orientasi fungsi (Siregar dalam Nugroho, 2002: 6).

\section{Keberagaman Kepemilikan dan Keberagaman Isi}

Dalam pasal 1 UU Nomor 32 Tahun 2002 menyebutkan bahwa "frekuensi radio adalah gelombang elektromagnetik yang dipergunakan untuk penyiaran dan merambat di udara serta ruang angkasa tanpa sarana pengantar buatan, merupakan ranah publik dan sumberdaya alam terbatas”. Sebagai sumberdaya alam milik publik maka sesuai dengan amanat pasal 33 Konstitusi negara kita, maka akan dikelola oleh negara dan dipergunakan untuk sebesar-besar kemakmuran rakyat.

Persoalannya, sejauh mana telah dipertimbangkan dampak-dampak buruk yang mungkin timbul jika satu kelompok usaha menguasai sedemikian banyak frekuensi- yang notabene adalah ranah publik - baik untuk kepentingan industri televisi maupun radio? Apakah penguasaan frekuensi yang cenderung monopolistik itu telah mempertimbangkan aspek keadilan dan keseimbangan? (Sudibyo, 2004: 45), atau apakah rakyat dapat termakmurkan oleh keberadaan frekuensi yang menjadi milik publik tersebut?

Ketentuan undang-undang penyiaran menyebutkan bahwa pemusatan kepemilikan dan penguasaan lembaga penyiaran swasta oleh satu orang atau satu badan hukum, baik di satu wilayah siaran maupun di beberapa wilayah siaran, dibatasi (Pasal 18 (1) UU Nomor 32 Tahun 2002). Selain ketentuan tersebut, kepemilikan silang antara jasa penyiaran radio, televisi, maupun media cetak juga dibatasi, tetapi ketentuan ini diatur dalam peraturan yang lebih khusus lagi.

Dalam Pasal 28 F UUD 45 sudah disebutkan bahwa setiap orang berhak untuk berkomunikasi dan memperoleh informasi. Bagi negara demokratis seperti Indonesia, maka media penyiaran adalah pilar keempat demokrasi yang berfungsi antara lain melakukan pengawasan terhadap jalannya kekuasaan. Media penyiaran berfungsi menjamin terselenggaranya arus bebas lalu lalang informasi secara bebas dari infrastruktur politik ke suprastruktur politik, dari infrastruktur politik ke infrastruktur politik, atau dari suprastruktur politik ke suprastruktur politik itu sendiri. Karena itu media penyiaran harus bebas dari intervensi penyelenggaraan kekuasaan (Pandjaitan dan Siregar, 2003: 138). Dalam agenda sistem komunikasi Indonesia yang kelima, yang disampaikan oleh Nurudin (2004: 207-208) bahwa peran media massa menjadi sangat penting di tengah komunitas masyarakat yang kian besar. Media menjadi unsur penghubung antar berbagai komponen masyarakat. 
Oleh karenanya disatu sisi media penyiaran perlu didorong dan dijamin secara bebas memenuhi hak asasi manusia untuk berkomunikasi dan memperoleh informasi, disisi lain jumlah ranah publik untuk media penyiaran terbatas. Kegiatan penyiaran, khususnya radio dan televisi menggunakan spektrum frekuensi radio yang merupakan bagian kecil gelombang elektromagnetik. Kegiatan penyiaran yang menggunakan ranah publik ini juga berdampak luar biasa terhadap masyarakat Indonesia baik dari segi politik, sosial budaya, maupun ekonomi. Itu berarti selain berurusan dengan distribusi frekuensi yang bersifat teknis, juga berhubungan dengan isi (content). Dengan demikian pengaturan tersebut harus sekaligus menyangkut frekuensi dan isi, yang harus dilakukan berdasarkan prinsip diversity of ownership dan diversity of content untuk sebesar-besarnya kepentingan dan kebutuhan publik (Pandjaitan dan Siregar, 2003: 171).

Dalam sebuah negara demokrasi dimanapun di dunia ini, peran masyarakat atau peran civil society amat besar dalam usaha melakukan pemerataan informasi (Pandjaitan dan Siregar, 2003: 166). Sejalan dengan hal tersebut, analisis Mc.Quail (dalam Morissan dkk, 2010: 63) tentang bagaimana produksi berita dalam media, media massa dalam menyebarkan berita tidak boleh hanya memberikan perhatian pada satu isu tertentu saja. Prinsip keragaman berita (diversity) adalah upaya media untuk menyajikan berita yang lengkap dengan menggunakan prinsip keadilan (fairness).

Selama ini televisi membuat acara lepas dari mainstream pemikiran masyarakat. Mereka cenderung lebih menentukan sajian acaranya. Termasuk disini UU Penyiaran itu akan merangsang munculnya televisi daerah. Fenomena ini tentu akan semakin mendorong pengembangan daerah yang selama ini selalu dimonopoli "pusat". Televisi daerah diharapkan mampu mewadahi kepentingan daerah dan apa yang harus dilakukan ke depan (Nurudin, 2004: 98). Jangkauan penyiaran dibatasi dengan tujuan menumbuhkan diversitas baik dalam ownership dan akhirnya dalam content. Pembatasan ini juga akan mendorong tumbuhnya media-media yang lebih berbasis pada daerah, sesuai dengan nafas pengembangan otonomi daerah (Pandjaitan dan Siregar, 2003: 83).

Khusus untuk di Indonesia, keberagaman kepemilikan media massa televisi dapat dilihat dengan dimungkinkannya beberapa bentuk penyelenggaraan jasa penyiaran yang dicantumkan dalam pasal 13 ayat (2) Undang-undang No. 32 Tahun 2002, antara lain : 1) Lembaga penyiaran publik; yaitu lembaga penyiaran yang berbentuk badan hukum yang didirikan oleh negara, bersifat independen, netral, tidak komersial, dan berfungsi memberikan layanan untuk kepentingan masyarakat; 2) Lembaga penyiaran swasta; adalah lembaga yang bersifat komersial berbentuk badan hukum Indonesia, yang bidang usahanya hanya menyelenggarakan jasa penyiaran radio atau televisi; 3) Lembaga penyiaran komunitas; adalah lembaga penyiaran yang berbentuk badan hukum Indonesia, didirikan oleh komunitas tertentu, bersifat independen dan tidak komersial, dengan daya pancar rendah, luas jangkauan wilayah terbatas serta untuk melayani kepentingan komunitasnya; dan 4) Lembaga penyiaran berlangganan; yaitu lembaga penyiaran berbentuk badan hukum Indonesia, yang bidang usahanya hanya menyelenggarakan jasa penyiaran berlangganan dan wajib terlebih dahulu memperoleh izin penyelenggaraan penyiaran berlangganan.

Keempat jenis jasa penyiaran kemudian mempunyai andil dalam menyemarakkan dan memberikan warna dalam isi media. Selain itu pula ditambah lagi adanya aturan lain dalam hal isi media televisi yaitu: 1) wajib mengandung informasi, pendidikan, hiburan, dan manfaat untuk pembentukan intelektualitas, watak, moral, kemajuan, kekuatan bangsa, menjaga persatuan dan kesatuan, serta mengamalkan nilai-nilai agama dan budaya Indonesia; 2) wajib memuat sekurangkurangnya $60 \%$ mata acara yang berasal dari dalam negeri; 3) wajib memberikan perlindungan dan pemberdayaan kepada khalayak khusus yaitu anak-anak dan remaja; 4) wajib menjaga netralitas; 5) dan lain-lainnya yang bersifat negatif (Pasal 36 Undang-Undang No. 32 Tahun 2002) 


\section{Keadilan Informasi}

Dengan diterbitkannya aturan di bidang penyiaran ini, maka kemudian banyak bermunculan industri jasa penyiaran di seluruh daerah-daerah di Indonesia. Hampir di setiap wilayah di Indonesia kini telah memiliki stasiun televisi swasta maupun publik yang sifatnya lokal. Jika dulu sebelum diundangkannya undang-undang tentang penyiaran ini penyiaran televisi didominasi oleh lembaga penyiaran yang me-nasional, dan hanya TVRI yang mempunyai lembaga penyiaran yang sifatnya lokal yang mengudara hanya di daerah-daerah tertentu saja dan isinya juga bersifat lokal, tapi sekarang lembaga penyiaran yang sifatnya lokal tidak hanya berupa TVRI programa daerah saja tetapi juga berupa lembaga penyiaran televisi swasta lokal.

Hal ini karena didukung oleh ketentuan yang diatur dalam pasal 6 ayat (3) dikatakan bahwa : Dalam sistem penyiaran nasional terdapat lembaga penyiaran dan pola jaringan yang adil dan terpadu yang dikembangkan dengan membentuk stasiun jaringan dan stasiun lokal. Khusus untuk lembaga penyiaran swasta yang harus diselenggarakan dengan pola berjaringan tersebut maka dalam aturan pelaksananya yaitu dalam Peraturan Pemerintah (PP) nomor 50 tahun 2005, dalam pasal 34 sebagai berikut: 1) Sistem stasiun jaringan terdiri atas Lembaga Penyiaran swasta induk satsiun jaringan dan Lembaga Penyiaran Swasta anggota stasiun jaringan yang membentuk sistem stasiun jaringan; 2) Lembaga Penyiaran Swasta induk stasiun jaringan merupakan Lembaga Penyiaran Swasta yang bertindak sebagai koordinator yang siarannya direlay oleh Lembaga Penyiaran Swasta anggota stasiun jaringan dalam sistem stasiun jaringan; 3) Lembaga Penyiaran Swasta anggota stasiun jaringan merupakan Lembaga Penyiaran Swasta yang tergabung dalam suatu sistem stasiun jaringan yang melakukan relay siaran pada waktu-waktu tertentu dari Lembaga Penyiaran Swasta induk stasiun jaringan; 4) Lembaga Penyiaran Swasta anggota stasiun jaringan sebagaimana dimaksud pada ayat (3) hanya dapat berjaringan dengan 1 (satu) Lembaga Penyiaran Swasta induk stasiun jaringan; 5) Lembaga Penyiaran Swasta jasa penyiaran radio dan/atau jasa penyiaran televisi yang menyelenggarakan siarannya melalui sistem stasiun jaringan harus memuat siaran lokal; 6) Setiap penyelenggaraan siaran melalui sistem stasiun jaringan dan setiap perubahan jumlah anggota stasiun jaringan yang terdapat dalam sistem stasiun jaringan wajib dilaporkan kepada menteri.

Hal yang penting untuk diketahui bahwa dalam ketentuan selanjutnya (pasal 36 PP nomor 50 tahun 2005) bahwa stasiun induk dari jaringan lembaga penyiaran swasta berada pada ibukota provinsi, selain itu juga disebutkan bahwa jangkauan wilayah siaran dari suatu sistem stasiun jaringan dibatasai paling banyak 75 \% dari jumlah provinsi di Indonesia kecuali bagi lembaga penyiaran yang sudah lebih dulu mempunyai jaringan lebih dari $75 \%$ tersebut sebelum aturan ini dibuat, tetapi tidak boleh lebih dari $90 \%$ dari jumlah seluruh provinsi yang ada di Indonesia.

Jika diurutkan kembali ke belakang, maka berkembangnya pertelevisian di Indonesia adalah karena diakuinya hak atas kebebasan untuk berekspresi seperti yang disampaikan dalam Piagam Perserikatan Bangsa-Bangsa (Universal Declaration of Human Rights) yaitu : Everyone has the right to freedom of opinion and expression; this right includes freedom to hold opinions without interference and to seek, receive and impart information and ideas through any media and regardless of frontiers (http://www.un.org/en/documents/udhr/). Sejalan dengan hal tersebut, Indonesia sebagai sebuah negara demokrasi juga memberikan pengakuan terhadap adanya kebebasan dalam menyampaikan pendapat dan berekspresi. Pengakuan tersebut telah dituangkan dalam Konstitusi Negara Republik Indonesia yaitu Undang-Undang Dasar 1945 khususnya pada pasal 28F yaitu : Setiap orang berhak untuk berkomunikasi dan memperoleh informasi untuk mengembangkan pribadi dan lingkungan sosialnya, serta berhak untuk mencari, memperoleh, memiliki, menyimpan, mengolah, dan menyampaikan informasi dengan menggunakan segala jenis saluran yang tersedia.

Sementara itu kita menyadari bahwa media penyiaran adalah medium raksasa yang setiap saat hadir sebagai ruang publik untuk menjadi cermin bagi siapapun yang menontonnya atau mendengarkannya. Ia merupakan alun-alun demokrasi modern. Begitu besar dan begitu dasyat 
dampaknya bagi keberlangsungan kehidupan dan kebudayaan (Nugroho, dalam Panjaitan dan Siregar, 2003: 5). Membudayakan televisi berarti menjadikan televisi bagian yang fungsional dari perkembangan kebudayaan. Ia harus hadir di tengah masyarakat, dan bersama masyarakat ikut berproses membentuk sosok kebudayaan masyarakat. Itu berarti pula bahwa televisi akan menjadi bagian dari proses dialektik membentuk kebudayaan masyarakat (Kayam, dalam Mulyana \& Ibrahim, 1997: 328, dalam Sobur, 2003: 185)

Fungsi media penyiaran televisi juga telah disesuaikan dengan situasi dan kondisi keIndonesiaan- maka fungsi keberadaan media massa khususnya penyiaran bagi masyarakat Indonesia telah ditetapkan secara normatif, terutama bagaimana keberadaan media penyiaran juga dapat mewujudkan situasi yang diinginkan yang tercantum dalam asas dan tujuan dari komunikasi dalam bidang penyiaran di Indonesia. Hal ini kemudian diakomodasi dalam Undang Undang No. 32 Tahun 2002 tentang Penyiaran.

Pada awalnya, perkembangan inovasi televisi adalah berawal dari kapasitas untuk mentransmisikan banyak gambar dan suara siaran langsung dan oleh karenanya ini dianggap sebagai “jendela dunia” pada real time (Mc.Quail, 2000: 25), namun sekarang keberadaan televisi tidak dapat kita lihat hanya sebagai sebuah benda mati yang mewakili keberadaan sebuah teknologi komunikasi. Banyak sekali pihak-pihak yang terlibat dengan semakin eksistensinya sebuah benda yang bernama televisi itu terutama dengan bagaimana isi yang ditampilkan di dalamnya. Pihak-pihak eksternal dan internal media yang punya potensi untuk mempengaruhi isi media tentunya telah melakukan tarik menarik dalam ikut menentukan isi media yang ditampilkan.

Sehingga dari uraian di atas maka dapatlah kita ambil kesimpulan bahwa isi media sarat akan kepentingan. Isi media bukanlah sesuatu yang tampil apa adanya, karena banyak hal-hal baik eksternal maupun internal yang membentuk isi media yang diproduksi. Oleh karenanya studi lebih lanjut yang dapat dianalisa adalah bagaimana mengatur kepemilikan media agar tercipta informasi yang sesuai dengan kebutuhan dan bagaimana fungsi media bagi masyarakat. Berbagai studi ini telah menggambarkan bahwa seringkali dalam industri penyiaran televisi terjadi persoalan antara kebutuhan untuk terus bertahan dan mendapatkan keuntungan yang berhadapan dengan kepentingan masyarakat akan informasi terutama jika dikaitkan dengan nilai-nilai norma dan budaya, dan yang terjadi adalah isi media seringkali lebih berpihak pada kepentingan ekonomi.

Jika demikian keadaannya, maka kepemilikan terhadap media jelas berpengaruh pada apa yang akan ditampilkan dalam isi media, dan akan semakin penting untuk dipersoalkan bagaimana jika terjadi beberapa media dikuasai oleh seorang pemilik saja. Padahal jelas kita ketahui bahwa adalah hak setiap orang untuk berkomunikasi dan bagaimana pula dengan dampak yang ditimbulkan akibat isi media terhadap masyarakat yang menerimanya.

Pengaturan terhadap aturan main dalam media penyiaran televisi (dan radio) perlu disediakan, karena karakteristik dari media penyiaran itu sendiri yang melibatkan pemanfaatan terhadap sumber daya alam milik publik (public domain) yaitu gelombang radio, sehingga menyebabkan aturan main dalam media penyiaran tidak bisa disamakan dengan media cetak. Dari beberapa ketentuan mengenai penyiaran televisi yang diuraikan di atas, maka sebenarnya pembuat undang-undang juga telah menyadari bagaimana peran dan fungsi media televisi dalam masyarakat dan bagaimana keberadaan penyiaran televisi dapat diselenggarakan benar-benar untuk sebesar-besar kemakmuran rakyat dan diterima keberadaannya sesuai fungsi media massa televisi tersebut bagi masyarakat.

Beberapa hal yang dapat penulis sarikan mengenai aturan-aturan tentang penyiaran yang diuraikan di atas yang dapat mewujudkan asas keadilan antara lain :

Pembatasan jangkauan siaran televisi akan memberikan kesempatan kepada masyarakat lokal untuk memanfaatkan gelombang radio yang tersedia dan membangun penyiaran televisi yang sesuai 
dengan lokalitas daerahnya dan membangun serta memelihara norma, budaya, dan nilai-nilai lokal yang dijunjung tinggi di masing-masing daerah. Hal ini dapat dibuktikan sekarang bahwa jika kita pergi ke daerah-daerah lain di luar Jakarta akan banyak ditemui siaran televisi dengan menggunakan bahasa daerah.

Keberadaan lembaga penyiaran televisi lokal akan membuat isi siaran "terasa lebih lokal”. Masyarakat di luar Jakarta tidak akan dijejali lagi dengan informasi yang bersifat "Jakarta-sentris". Masyarakat menjadi punya pilihan terhadap informasi yang tersedia. Selain itu masyarakat lokal juga dapat menentukan isi siaran apa yang ingin disajikan yang sesuai dengan kebutuhan daerahnya.

Pembatasan isi siaran yang $60 \%$ harus merupakan mata acara yang berasal dari dalam negeri akan mendorong munculnya industri-industri kreatif untuk mengisi program-program tayangan televisi. Akibat selanjutnya adalah banyaknya tenaga kerja yang terserap dalam bidang yang berkaitan dengan industri penyiaran televisi ini, baik di Jakarta maupun di daerah-daerah dimana lembaga penyiaran televisi lokal berada. Dengan demikian, daerah tidak lagi hanya "dititipi" tiang pemancar tetapi juga dapat mengambil manfaat secara ekonomi dari keberadaan lembaga penyiaran televisi.

Kebutuhan akan sumberdaya manusia dalam memenuhi kebutuhan informasi ini juga turut memajukan dunia pendidikan dalam rangka terus melahirkan mereka-mereka yang dibutuhkan keahliannya dalam bidang komunikasi.

Masyarakat lokal juga dapat mempunyai akses yang lebih mudah untuk menjangkau media, mereka dapat memanfaatkan media televisi lokal untuk dijadikan ruang publik (public sphere) guna mendiskusikan persoalan-persoalan di wilayahnya.

Hal yang lebih penting lainnya adalah lembaga penyiaran televisi lokal dapat menjadi jembatan penghubung antara masyarakat dan suprastruktur politik. Pertarungan politik lokal tidak perlu lagi "menyewa" lembaga penyiaran dengan jangkauan nasional untuk menampilkan kampanyekampanye politik lokal, karena akan sangat menghabiskan biaya dan masyarakat daerah lain yang tidak memiliki kepentingan terhadap kebutuhan politik daerah lain juga akan dapat menyaksikan kampanye-kampanye politik daerah lain tersebut.

\section{SIMPULAN}

Media penyiaran merupakan institusi yang memerlukan regulasi, dengan maksud disatu pihak untuk menjamin otonominya, dan pada pihak lain menjamin hak warga untuk memanfaatkan media penyiaran. Sesuai dengan amanat Konstitusi maka segala pamanfaatan sumber daya alam milik publik harus dilaksanakan untuk sebebsar-besar kemakmuran rakyat, oleh karenanya keberadaan lembaga penyiaran televisi di Indonesia harus dapat menjamin keadilan khususnya dibidang informasi. Media massa tampil pada hakekatnya adalah untuk memenuhi hak masyarakat untuk mengetahui, sehingga apa yang ditampilkan dalam isi media seharusnya memang untuk memenuhi kebutuhan informasi masyarakat. Hal ini sesuai dengan apa yang telah diamanatkan oleh undang-undang tentang penyiaran. Selain itu hak masyarakat untuk mengetahui informasi juga harus dibarengi dengan memberikan informasi sesuai dengan apa yang dibutuhkan oleh masyarakat secara adil. Keadilan informasi ini pada akhirnya akan membawa dampak ikutan yang cukup penting bagi masyarakat, yaitu terlibatnya masyarakat akan keberadaan media baik dalam bidang sosial dan ekonomi. 


\section{DAFTAR PUSTAKA}

Mc.Quail, D. (2000). Mc.Quail’s Mass Communication Theory. Sage Publications.

Morissan, Wardhani AC, Hamid F. (2010).Teori Komunikasi Massa. Jakarta: Ghalia Indonesia.

Mufid, M.(2005). Komunikasi dan Regulasi Penyiaran. Kencana. Jakarta.

Nugroho, G. (2002). TV Publik, Menggagas Media Demokratis di Indonesia. Jakarta: Yayasan Sains Estetika dan Teknologi.

Nurudin. (2004). Sistem Komunikasi Indonesia. Jakarta: PT. Raja Grafindo.

Pandjaitan, Hinca IP dan Amir E Siregar.(2003).Membangun Sistem Penyiaran yang Demokratis di Indonesia. P.T. Warta Global Indonesia.

Republik Indonesia. Undang-undang Republik Indonesia Nomor 32 Tahun 2002 tentang Penyiaran. LNRI tahun 2002 nomor 139. TLNRI nomor 4252

Peraturan Pemerintah (PP) nomor 50 tahun 2005 tentang Penyelenggaraan Penyiaran Lembaga Penyiaran Swasta. LNRI tahun 2005 nomor 127. TLNRI 4566

Shoemaker, Pamela J. Stephen D Reese. (1995). Mediating the Message, Theories of Influences on Mass Media Content. 2nd ed. Longman.

Sobur, A. (2003). Semiotika Komunikasi. Bandung: PT. Remaja Rosdakarya.

Sudibyo, A. (2004). Ekonomi Politik Media Penyiaran. LKIS. 